\section{A Case of Spontaneous Pneumothorax with Persistent Air Leakage During the Course of COVID-19}

\author{
COVID-19 Seyri Sırasında Persistan Hava Kaçağı \\ Olan Spontan Pnömotoraks Olgusu
}

\section{Saliha Kanık Yüksek $\odot$ Aslınur Özkaya Parlakay ๑ Doğuş Güney • Belgin Gülhan ๑ Gülsüm İclal Bayhan ๑ Emrah Şenel $\odot$}

\section{ABSTRACT}

Development of pneumothorax during the course of COVID-19 is very rare, and may occur secondary to severe pulmonary involvement causing alveolar damage in the parenchyma, or is seen as a complication of respiratory support. Until now, quite a few cases have been reported. Herein, we shared a case of spontaneous pneumothorax with persistent air leakage without any parenchymal or pleural involvement.

Keywords: Pneumothorax, COVID-19, thoracotomy, air leakage

öz

COVID-19 seyri sırasında pnömotoraks çok nadirdir, parankimde alveolar hasara neden olan ciddi pulmoner tutuluma ikincil olarak ortaya çıkabilir veya solunum desteğinin bir komplikasyonu olarak görülür. Şimdiye kadar çok az sayıda vaka bildirilmiştir. Burada herhangi bir parankimal veya plevral tutulum olmaksızın persistan hava kaçağı olan spontan pnömotoraks olgusunu paylaştık.

Anahtar kelimeler: Pnömotoraks, COVID-19, torakotomi, hava kaçağı
Received: 09.11 .2020

Accepted: 09.02.2021

Published Online: 03.08.2021

Cite as: Kanık Yüksek S, Özkaya Parlakay A, Güney D, Gülhan B, Bayhan Gi, Senel E. A case of spontaneous pneumothorax with persistent air leakage during the course of COVID-19. İzmir Dr. Behçet Uz Çocuk Hast. Dergisi. 2021;11(2):202-5.

Saliha Kanık Yüksek
Sağlık Bilimleri Üniversitesi,
Ankara Şehir Hastanesi,
salihakanik@gmail.com
Ankara, Türkigi,
Çocuk Enfeksiyon Hastalılar
ORCiD: 0000-0002-2538-2872
A. Ozkaya Parlakay 0000-0001-5691-2461
B. Gülhan 0000-0003-0839-1301
G. Iclal Bayhan 0000-0002-1423-4348
Sağlık Bilimleri Üniversitesi,
Ankara Şehir Hastanesi,
Çocuk Enfeksiyon Hastalıkları Kliniği,
Ankara, Türkiye
D. Güney 0000-0001-7168-2123
E. Şenel 0000-0002-0383-4559
Sağlık Bilimleri Üniversitesi,
Ankara Şehir Hastanesi,
Çocuk Cerrahisi Hastalıkları Kliniği,
Ankara, Türkiye

\section{INTRODUCTION}

An emerging infectious disease that causes pneumonia associated with SARS-CoV2 was initially reported in December 2019 in Wuhan City of People's Republic of China, and was named as coronavirus disease 2019 (COVID-19) ${ }^{(1)}$. Although the situation was declared as a pandemic, many unknowns about this disease were on the agenda (2). Although it is known that the infection primarily affects the lung, the involvement patterns were being defined as time progressed ${ }^{(2,3)}$. Individual or combined images of ground glass opacification(s), interlobular septal thickening, bronchiectasis, pleural thickening, subpleural involvement, and consolidative opacities on computed tomography (CT) were identified as the characteristic features for COVID 19 pneumonia (3). Pleural effusion, cavitation, halo sign, and spontaneous pneumothorax were less common radiological manifestations in large case series ${ }^{(3,4)}$. Herein, we would like to share our experience with an extremely rare pediatric case of spontaneous pneumothorax

(c) Copyright İzmir Dr. Behçet Uz Children's Hospital. This journal published by Logos Medical Publishing

Licenced by Creative Commons 4.0 International (CC BY) 
with persistent air leakage seen during the course of COVID-19 disease.

\section{CASE REPORT}

A previously healthy 17 -year-old male patient was admitted with the complaints of fever and weakness. A naso-oropharyngeal swab sample was obtained, and examined for COVID-19 by Real-Time Reverse Transcription Polymerase Chain Reaction
(RT-PCR) method (Bioeksen, Istanbul, Turkey) which yielded a positive result. Since physical examination findings, routine blood test results and thorax CT scans were not remarkable, outpatient monitoring without treatment was planned for the patient. However, the patient was re-admitted nine days after the positive RT-PCR test result was obtained due to newly developed chest pain and shortness of breath. Respiratory distress, low oxygen saturation and decreased respiratory sounds were detected on

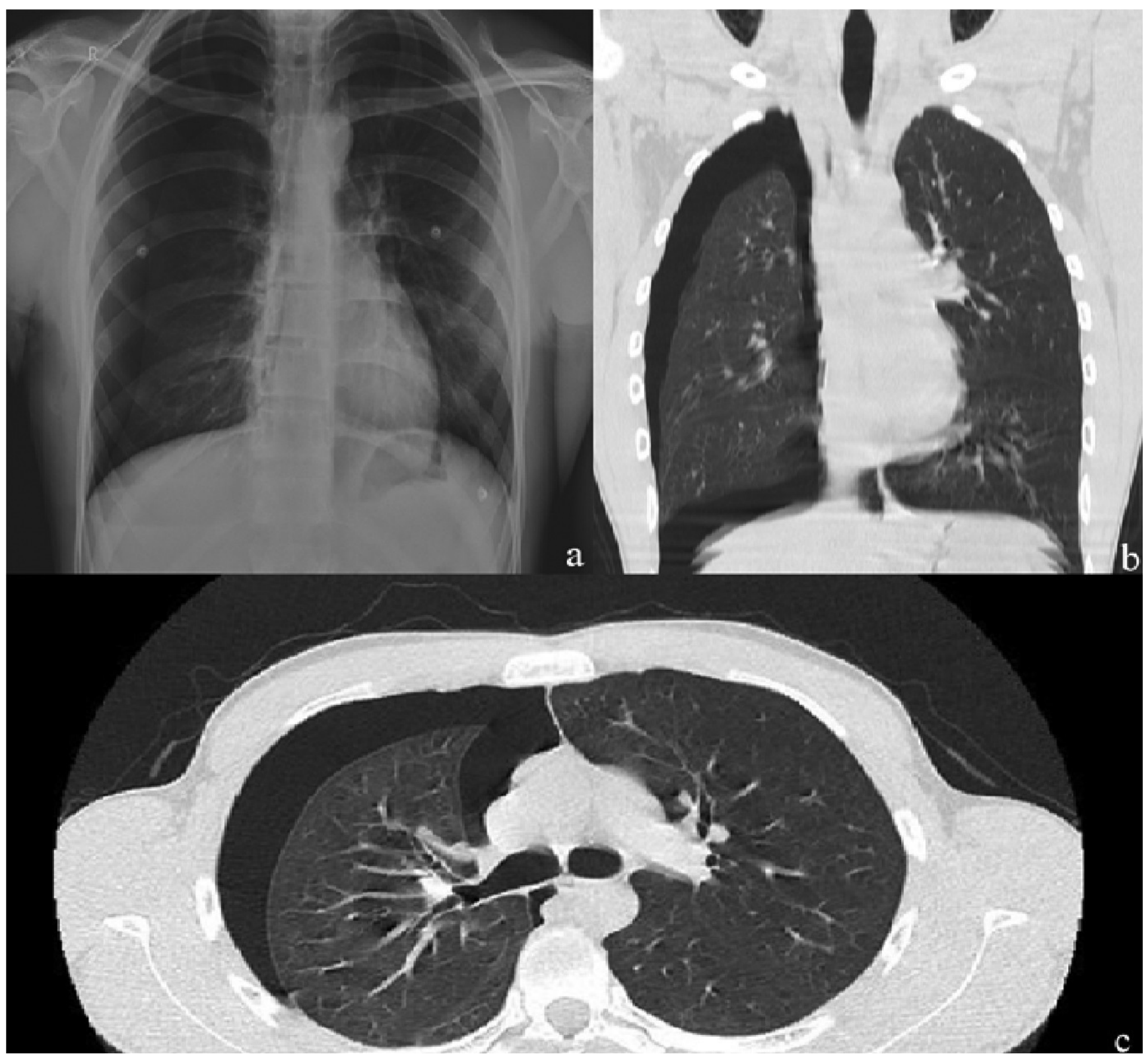

Figure 1. Pneumothorax sign in the right hemithorax of the patient, on chest X-ray (a) and in coronal (b) and horizontal (c) sections of thorax computed tomography. 


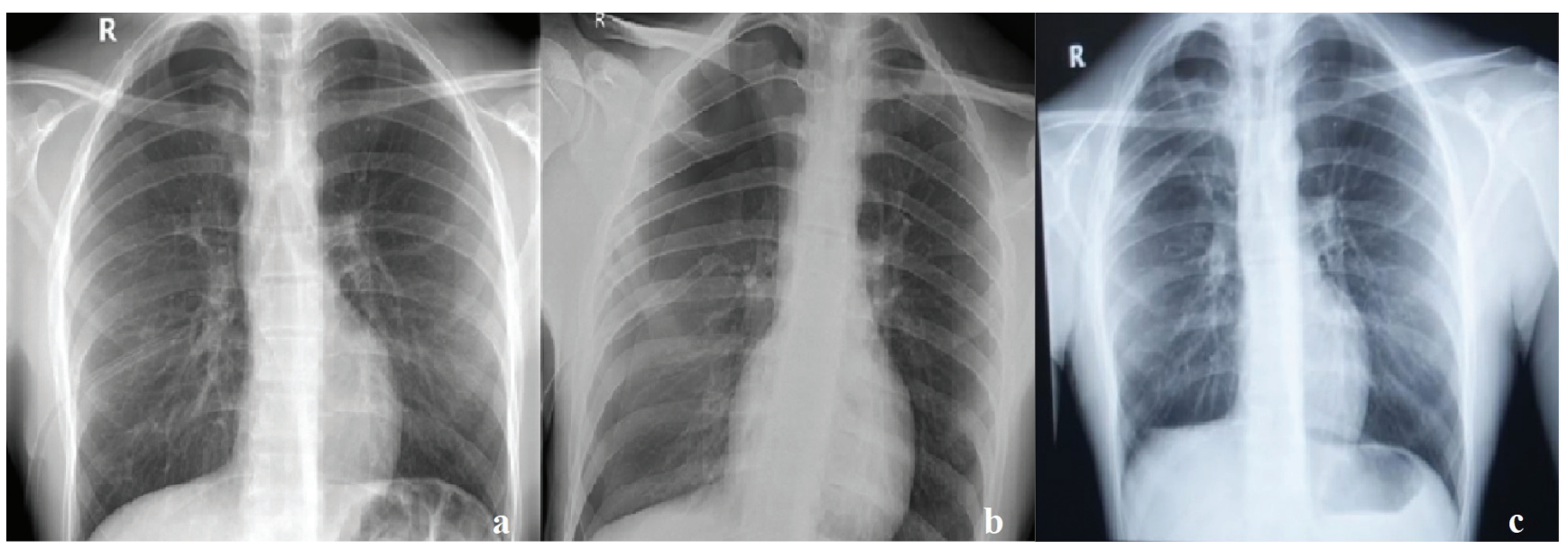

Figure 2. Completely ventilated right hemithorax of the patient after chest tube insertion (a), new sign of pneumothorax on the control radiograph after clamping of the chest tube (b), and postoperative X-ray of the patient during monitorization with thoracic drainage suction pump (c).

the examination. Hemogram, blood biochemistry, cardiac enzymes and acute phase reactants were all within normal limits. Creatinine kinase level was elevated and analysis of arterial blood gas revealed the presence of hypoxemia. A pneumothorax sign in the right hemithorax on chest X-ray (Figure-1a), and thorax CT without any pathological findings in the lung parenchyma confirmed the diagnosis (Figure-1b/1c). A chest tube was inserted into the pleural space by the pediatric surgery clinic. After the procedure, the patient's respiratory distress quickly resolved, the right hemithorax was re-expanded and the pneumothorax sign disappeared on the control radiograph (Figure 2a).

Prophylactic treatment with sulbactam-ampicillin was initiated, and a specific treatment for COVID-19 was not given. The patient was monitored asymptomatically in the first week of hospitalization and the chest tube was clamped on the seventh day. However, patient described a chest pain after clamping of the tube, and a new pneumothorax sign appeared on chest X-ray (Figure 2b). Despite several attempts at removal of the chest tube on different days, the patient could not tolerate the procedure, and the tube was revised. After three weeks of follow-up, a bullectomy, partial pleurectomy and pleurodesis were applied with linear stapings to the right upper lobe apex by performing right thoracoscopy. However, thoracoscopy was switched to thoracotomy as the air leak continued during the operation. Any promi- nent fistula line was not detected, and patient was connected to the thoracic drainage suction pump (Figure 2c). After monitoring with the thoracic drainage suction pump, the patient was discharged asymptomaticly on the postoperative 23rd day. Any other risk factors for spontaneous pneumothorax such as chronic or previous respiratory tract disease, smoking, tall and thin body structure, or regular risky sportive activities were not identified.

\section{DISCUSSION}

Pneumothorax in the course of COVID-19 has been rarely reported as a possible finding that can be seen with disease progression ${ }^{(3)}$. In the cases previously reported, it has been expressed that pneumothorax occurs secondary to severe involvement causing alveolar damage or bullous lesions in the parenchyma, or is seen as a complication after noninvasive ventilation or positive pressure respiratory support ${ }^{(5)}$. In the case series reported by Eperjesiova et al, it was stated that all seven patients, who did not receive ventilation support before, developed COVID-19-related spontaneous pneumothorax, had typical images of COVID-19 parenchymal damages on their CT scans that could predispose to pneumothorax ${ }^{(6)}$. Pneumothorax in the course of COVID 19 is very rare also in children. Until now, a few pediatric cases have been reported including two newborns with parenchymal lesions of the infec- 
tion and a 14-year-old patient who underwent a bullectomy operation ${ }^{(7,8)}$. It is notable that pneumothorax developed in our patient who had not any predisposing factors that may facilitate development of pneumothorax.

To our knowledge, COVID 19-related spontaneous pneumothorax without any parenchymal or pleural involvement has not been reported so far. It is also noteworthy that although there is no facilitating factor, the pneumothorax was serious enough to require surgery and did not benefit from the interventions for a while.

\section{Conflict of Interest: None.}

Informed Consent: Obtained from the patient's relatives.

\section{REFERENCES}

1. Li Q, Guan X, Wu P, Wang X, Zhou L, Tong Y, et al. Early transmission dynamics in Wuhan, China, of novel coronavirusinfected pneumonia. N Engl J Med. 2020;382(13):1199-207. https://doi.org/10.1056/NEJMoa2001316
2. Jee Y. WHO International Health Regulations Emergency Committee for the COVID19 outbreak. Epidemiol Health. 2020;42:e2020013. https://doi.org/10.4178/epih.e2020013

3. Salehi S, Abedi A, Balakrishnan S, Gholamrezanezhad A. Coronavirus Disease 2019 (COVID-19): A Systematic Review of Imaging Findings in 919 Patients. AJR Am J Roentgenol. 2020;215(1):87-93. https://doi.org/10.2214/AJR.20.23034

4. Yang F, Shi S, Zhu J, Shi J, Dai K, Chen X. Analysis of 92 deceased patients with COVID-19. J Med Virol. 2020:10.1002/ jmv.25891. https://doi.org/10.1002/jmv.25972

5. López Vega JM, Parra Gordo ML, Diez Tascón A, Ossaba Vélez S. Pneumomediastinum and spontaneous pneumothorax as an extrapulmonary complication of COVID-19 disease. Emerg Radiol. 2020:1-4. https://doi.org/10.1007/s10140-020-01806-0

6. Eperjesiova B, Hart E, Shokr M, Sinha P, Ferguson GT. Spontaneous Pneumomediastinum/Pneumothorax in Patients With COVID-19. Cureus. 2020;12(7):e8996. https://doi.org/10.7759/cureus.8996

7. Coronado Munoz A, Nawaratne U, McMann D, Ellsworth $M$, Meliones J, Boukas K. Late Onset Neonatal Sepsis in a Patient with Covid-19. N Engl J Med. 2020;382(19):e49. https://doi.org/10.1056/NEJMc2010614

8. Giné C, Laín A, García L, López M. Thoracoscopic Bullectomy for Persistent Air Leak in a 14-Year-Old Child with COVID-19 Bilateral Pulmonary Disease. J Laparoendosc Adv Surg Tech A. 2020 Jun 11. https://doi.org/10.1089/lap.2020.0289 